\title{
Oor die teologiese inhoud van die Nederlandse Geloofsbelydenis vandag ${ }^{1}$
}

\section{ABSTRACT \\ On the theological content of the Confessio Belgica in the light of today}

The paper is an edited version of a public address during the 450 year celebration of the Confessio Belgica in the Faculty of Theology of Stellenbosch University. It reflects on the theological content of the Confessio Belgica in the light of today and with a deliberate focus on South African Reformed circles. In a first section the background claim is made that the theological content of Reformed confessional documents is always deeply related to their genesis and therefore to the historical circumstances under which they were originally adopted and in some cases also afterwards gradually accepted more broadly. A second section builds on the conviction that the theological content of such documents is therefore to be found in central convictions or claims (that were at stake, most probably disputed at the time), rather than in all and every detail. A few brief references serve as reminders of some historical South African Reformed debates about these central convictions of the Confessio Belgica. A third section considers some issues involved in so-called hermeneutics of tradition, in the Wirkungsgeschichte of confessional documents and in the ongoing reception of their relevance under new and radically different circumstances, in this case the totally different South African context and centuries later. In a final section, this process is illustrated by showing how the theological content of the Confessio Belgica became "liberating truth" again for some in South African Reformed circles, during the birth of the Confession of Belhar.

Dis onmoontlik om in dié kort tyd in te gaan op die teologiese inhoud van die Nederlandse Geloofsbelydenis (NGB) - daaroor word immers talle en omvangryke boeke geskryf. In SuidAfrika hoef ' $\mathrm{n}$ mens net te dink aan J.A. (Johan) Heyns se Inleiding in die Dogmatiek (1992). ${ }^{2}$

1 Hierdie bydrae is gebaseer op ' $n$ openbare voordrag tydens die amptelike herdenking in die Fakulteit Teologie, Stellenbosch, van die 450 jarige bestaan van die Nederlandse Geloofsbelydenis, op 22 November 2011. Die viering was in die vorm van 'n openbare simposium, waartydens prof. Hendrik Bosman en prof. Robert Vosloo ook voordragte gelewer het. Die oorspronklike vorm van die voordrag is hier onveranderd behou, maar voetnote met verwysings is bygevoeg ter wille van akademiese gebruik deur lesers.

2 Sien byvoorbeeld die werk van die gesaghebende dogmatikus van Pretoria, J.A. Heyns. Hy het reeds in 1978 'n Dogmatiek geskryf, Pretoria: NGKB, wat hy in die voorwoord beskryf as " $n$ "inleiding tot die dogmatiek." By die onderskeie loci verwys hy daarin direk na die betrokke gedeeltes in die Drie Formuliere van Eenheid, wyd bekend en aanvaar in die tradisie van Gereformeerde kerke van Nederlandse oorsprong. In 1992 skryf hy dan nóg 'n werk, nou met die titel Inleiding tot die dogmatiek aan die hand van die Nederlandse Geloofsbelydenis, Pretoria, NGKB, waarin hy voluit dié belydenisskrif as uitgangspunt neem - "as uitgangspunt en oriënteringsbron." Hy beskryf dit as "hierdie belangrike en nog steeds rigtinggewende belydenisgeskrif van ons kerk," met verwysing na die Ned. Geref. Kerk. In 
Boonop is dit ook nie nodig nie - aangesien die inhoud waarskynlik goed bekend is aan enige gehoor wat soos vanaand byeen kom om die ontstaan van dié Protestantse belydenisskrif 450 jaar gelede te herdenk. Laat ons daarom eerder dié geleentheid benut om na te dink oor vrae rondom die moontlike relevansie - of nié - van dié teologiese inhoud. Met die oog daarop maak ek drie inleidende stellings.

\section{TEOLOGIESE INHOUD INGEBED IN DIE ONTSTAANSGESKIEDENIS}

In die eerste plek word Protestantse belydenisskrifte altyd gebore in spesifieke sosiale en historiese omstandighede, as konkrete aanleiding tot hulle ontstaan. Hulle teologiese inhoud kan nie verstaan word los van dié politieke en kerklike oomblikke nie. Hulle is almal pogings om in konkrete situasies die evangelie opnuut te bely - gegee die uitdagings van die tyd, die veronderstellings en die voorstellings, die standpunte en strydgesprekke, die taalgebruik en konsepte van die tyd. ${ }^{3}$

Tegelyk hang hul waarheid nie af van die historiese oomblik, moontlike nut binne die sosiale en kerklike konteks, potensiële gedienstigheid aan ander strewes en motiewe nie, maar uitsluitlik van die vraag of die evangelie in dié oomblik van omstredenheid reg gehoor is, of nie. Hul waarheid is nie die waarheid van die oomblik nie, maar die waarheid van die evangelie vir die oomblik. ${ }^{4}$

Suid-Afrika is dikwels gebruik gemaak van standaard Nederlandse werke. Vir die oorspronklike tekste met annotasies, sien byvoorbeeld J.N. Bakhuizen van den Brink, De Nederlandse Belijdenisgeschriften, Amsterdam: Ton Bolland, 1976; vir uiteensettings en besprekings van die inhoud, sien byvoorbeeld die vier-delige werk van A.D.R. Polman, Onze Nederlandsche Geloofsbelijdenis. Verklaard uit het Verleden geconfronteerd met het Heden, Franeker: Wever, z.j., asook sy latere, meer populêr geskrewe twee-delige Woord en Belijdenis. Eenvoudige Verklaring van de Nederlandse Geloofsbelijdenis, Franeker: Wever, z.j. Volgens sy eie beskrywing is laasgenoemde nie net eenvoudiger geskryf nie, maar ook vanuit die Heilige Skrif belig eerder as vanuit die verlede (soos die vorige vier bande), wat beteken het dat "feitelijk een geheel nieuw werk ontstaan is."

3 Oor die tipies Gereformeerde siening van belydenis en belydenisskrifte, sien D.J. Smit, “'Bevrydende waarheid?' - Nagedink oor die aard van die Gereformeerde belydenis,” Acta Theologica jrg 26, 2006/1, 134-158 (met literatuur). Meer uitvoerig, sien ook E. Busch, Credo, Göttingen: Vandenhoeck \& Ruprecht, 2003; P. Jacobs, Theologie Reformierter Bekenntnisschriften in Grundzügen, Neukirchen: Neukirchener Verlag, 1959; W. Niesel, (Hrsg.) Bekenntnisschriften und Kirchenordnungen der nach Gottes Wort reformierten Kirche. Zürich: Evangelischer Verlag, 1938; W. Niesel, Das Evangelium und die Kirchen. Ein Lehrbuch der Symbolik, Neukirchen: Neukirchener Verlag, 1960; G. Plasger \& M. Freudenberg, Reformierte Bekenntnisschriften, Göttingen: Vandenhoeck \& Ruprecht, 2005; J. Rohls, J Theologie reformierter Bekenntnisschriften, Göttingen: Vandenhoeck \& Ruprecht, UTB, 1987; L. Vischer (ed), Reformed Witness today, Bern: Evangelische Arbeitsstelle, 1982.

4 Histories invloedryk, maar ook besonder leersaam vir vele Suid-Afrikaanse denkers was in hierdie verband die sieninge van Karl Barth rakende belydenis, die trou aan en die relevansie en "relatiewe gesag" van die ekumeniese credo's, die historiese en kontekstuele aard van Gereformeerde belydenisskrifte en die noodsaak wat kan ontstaan aan nuwe belydenisvorming, in oomblikke van waarheid. Sien hiervoor D.J. Smit, "Social transformation and confessing the faith? Karl Barth's views on confession revisited," Scriptura 72, 2000:1, 76-86 (met literatuur). Meer uitvoerig, sien G. Plasger, Die relative Autorität des Bekenntnisses bei Karl Barth, Neukirchen-Vluyn: Neukirchener Verlag, 2000; M. Freudenberg, Karl Barth und die reformierte Theologie, Neukirchen-Vluyn: Neukirchener Verlag, 1997; B. Klappert, Versöhnung und Befreiung, Neukirchen-Vluyn: Neukirchener Verlag, 1994; G. Plasger, “'Du sollst Vater und Mutter ehren!'. Karl Barth und die reformierte Tradition," in M. Beintker, C. Link \& M. Trowitzsch (Hrsg.), Karl Barth in Deutschland (1921-1935). Aubbruch $\square$ Klärung $\square$ Widerstand, Zürich: TVZ, 2005, 393-405. Van Barth self, sien byvoorbeeld Das Bekenntnis der Reformation und unser Bekennen. München: Chr. Kaiser Verlag, 1935; Wünschbarkeit und Möglichkeit eines allgemeinen 
Dis daarom nodig om tydens dié herdenking die dramatiese ontstaan van die Nederlandse Geloofsbelydenis in herinnering te roep, ten einde die diepe erns van wat op die spel was, die aard van die destydse konflikte en die reaksie van die belydenis op dié situasie met beroep op die evangelie te onthou en te respekteer.

In die nag van 1 Nov 1561 word 'n pakkie met die belydenis en ' $n$ begeleidende brief by die poort van die kasteel te Doornik gelaat. Dis geskryf deur Guido de Bres - toe die plaaslike predikant, ' $n$ kundige en belese teoloog, vroeër ' $n$ vlugteling en later ' $n$ martelaar wat sterf vir sy geloof. Die brief is ' $n$ passievolle pleidooi gerig aan die owerhede om nie voort te gaan om die Gereformeerde gelowiges te vervolg nie (omdat hul belydenis, soos uiteengesit in dié klein boekie, nie in stryd is met die klassieke geloof van die kerk nie en hul lewe en gedrag ook nie ongehoorsaam is aan die owerheid nie), maar met die duidelike bereidheid om te ly vir hul belydenis, indien die onregverdige vervolging sou voortduur. Wie die inhoud wil verstaan moet dié geskiedenis onthou. ${ }^{5}$

\section{TEOLOGIESE INHOUD TE VINDE IN DIE SENTRALE MOTIEWE}

In die tweede plek bestaan die blywende aansprake van belydenisskrifte gevolglik in dit wat hulle wil bely, in hul beslissings en getuienis in die konflik van die oomblik. In die uitleg van belydenisskrifte was dié saak dikwels hoogs omstrede en diep verdelend - óók in Suid-Afrika. Die spektrum van standpunte oor hul rol en gesag wissel nie slegs van dié wat min of geen gesag daaraan toeken tot by dié wat wel bely dat dit gesaghebbend en oriënterend is nie, maar ook laasgenoemde groep sélf is diep verdeeld, oor die vraag waarin die betroubaarheid en gesag setel. Ook hier is ' $n$ hele spektrum van sieninge en formuleringe wat deur die geskiedenis telkens weer sou lei tot ernstige meningsverskille.

Dié spektrum val ook nie saam met die sogenaamde verskil tussen quia (omdat) en quatenus (in soverre as) standpunte oor die verhouding tussen belydenisskrif en Skrif nie. Selfs binne die geledere van dié wat eerder die quia-standpunt onderskryf (omdat hulle besef dat quatenus ' $n$ niksseggende openheid tot willekeur en subjektiwistiese relatiwisme kan open), is daar naamlik 'n spektrum van standpunte moontlik, afhangende van die vraag waarin die ooreenstemming met die Skrifte gesoek word - vanaf letterlik elke moontlike formulering aan die een kant tot by "in gees en hoofsaak" aan die ander kant, 'n formulering wat in die geskiedenis eweneens arbitrêr benut is. ${ }^{6}$

reformierten Glaubensbekenntnisses, Vorträge und kleinere Arbeiten 1922-1925. Gesamtausgabe III. Zürich: Theologischer Verlag, 1990, 604-643; Die Theologie der reformierten Bekenntnisschriften 1923. Gesamtausgabe II. Zürich: Theologischer Verlag, 1998 (The theology of the reformed confessions, Louisville: Westminster John Knox, 2002, tr. D L \& J J Guder); Texte zur Barmer Theologischen Erklärung, Zürich: TVZ, 2004.

5 Sien byvoorbeeld die uiters indrukwekkende, nuwe werk wat onlangs in Nederland verskyn het, van die hand van E. Braekman \& E. de Boer (reds.), Guido de Bres. Zijn leven, zijn belijden, Utrecht, Uitgeverij Kok, 2011. Dié pragtige werk bevat nie alleen gesaghebbende opstelle oor ' $n$ wye verskeidenheid van historiese temas rondom De Bres self asook rondom die Nederlandse Geloofsbelydenis se ontstaan nie, maar oor lesenswaardige opstelle oor die verbreiding en nawerking van dié belydenisskrif, in vele dele van die wêreld.

6 Vir ' $n$ inleiding in die destydse debatte oor die aard van die gesag, sien byvoorbeeld D. Nauta, De verbindende kracht van de belijdenisschriften, 1969, Kampen: J H Kok. Vir 'n deeglike en 'n meer omvattende perspektief op die gesag van geloofsbelydenisse en belydenisskrifte as net die streng Gereformeerde uit Nederlandse kringe, sien J. Pelikan, Credo, New Haven: Yale, 2003, veral 245364. Pelikan formuleer wat hy bestempel as onaanvaarbare alternatiewe skerp maar helder: "A quia would seem to imply that loyalty to the teaching of these confessions is tantamount to loyalty to the teaching of Scripture. Critics found this implication concerning the confessions to represent an inherent 
Debatte hieroor sou hewig woed in Gereformeerde kringe wêreldwyd. ${ }^{7}$ Dit sou ook die resepsie van die Nederlandse Geloofsbelydenis stempel en uiteraard ook in Suid-Arikaanse geledere telkens weer opvlam en diepe verdelinge vestig en versterk, tot vandag. ${ }^{8}$ So sou Berkouwer byvoorbeeld op dié vrae ingaan in sy "Vragen rondom de belijdenis" (1963) en A.J. (Andries) Venter sou sy argumente plaaslik benut in Kerk en Belydenis (1965) in die reeks "Die Stryd om die Kerk." ${ }^{10}$ Dit gaan om "die totale struktuur," "die sentrale bedoeling," "sentrale motiewe," "beslissende grondmotiewe," "die diepste intensie," "die skopus," "die Bybelse lig wat deur die belydenis heen straal" - met al dié uitdrukkings soek Berkouwer om te sê waarin ware trou aan belydenisskrifte eintlik bestaan, in onderskeid van wat hy beskryf as "notariële" of "tekstualistiese" opvattinge.

Waarskynlik sal vele vandag ten minste in beginsel saamstem (al bied dit nog geen maklike rigsnoer in konkrete debatte nie) dat sulke belydenisse nie a-historiese, tyd- en kontekslose dokumente met ewige en finale formulerings is nie. Hulle inhoud - en daarmee hul blywende getuienis en krag - lê eerder in hulle strekking, religieuse motiewe, geestelike beslissings, in die insigte in die evangelie wat hulle verwoord, die diepe oortuigings wat hulle bely téénoor misleidende oortuigings in die lug. W.D. (Willie) Jonker praat in Bevrydende Waarheid (1994) van "swaartepunte" - óók in die Nederlandse Geloofsbelydenis. ${ }^{11}$

contradiction with the principle of sola Scriptura ... Did the Lutheran quia-subscription ... (and the Reformed equivalents of such subscription ...) smuggle the authority of the tradition back in - even when the tradition was the doctrine that only Scripture, and not tradition, was to be the authority? The reply to this objection was that a confessional subscription quatenus was meaningless and unenforceable. It provided only an illusory protection ... Subscribing to the creed only 'to the extent that' it agreed with Scripture carried with it no specification of just what that extent was. After all, as the rhetorical argument put it, a Christian could subscribe even to the Qur'ān to the extent that it harmonized with the Bible ... The other theological question ... is generically related to it: Does subscription to a creed or confession extend only to the doctrines stated in it, or also to other matters, to its historical, political, scientific, and moral judgments, and above all to its interpretations of specific passages of the Bible? Once again, the alternatives could be put in ways that were equally unpalatable," $271-272$. Presies hierdie tipe alternatiewe en hierdie soort debatte sou ook in Suid-Afrikaanse kringe gevoer word rondom die Nederlandse Geloofsbelydenis.

7 Besonder interessant met die oog op die Suid-Afrikaanse debatte, sien byvoorbeeld H. Berkhof, "Die toekoms van die Gerformeerde konfessie," Pro Veritate 1964/6, 1-2; asook W.D. Jonker, "Die moderne belydenisbeweging in Suid-Afrika - en Calvyn," In die Skriflig, 1993, 27 (4), 443-461 en veral die oorwoë W.D. Jonker, Bevrydende waarheid. Wellington: Hugenote-Uitgewers, 1994.

8 Sien byvoorbeeld die bydraes wat versamel is in H.L. Bosman et al (reds.), Die Nederlandse Geloofsbelydenis - Ontstaan, Skrifgebruik en Gebruik, Pretoria, UNISA, 1987. Dit was die produk van ' $n$ navorsingsprojek wat gefokus het op die Skrifgebruik in die Nederlandse Geloofsbelydenis, maar in die praktyk oor breër gewerk het en ook historiese bydraes en selfs empiriese resultate ingesluit het. Verder ook J. Buitendach, "Die belydenis van die kerk," Acta Theologica.Supplementum 3. Essentialia et Hodierna, 2002, 17-34 ; asook die werk van S.A. Strauss, byvoorbeeld in sy "Die aktualiteit van die NGB na vierhonderd vyf en twintig jaar," Fax Theologica 1986/2, 53-68; "Riglyne vir die etiek in die Drie Formuliere van Eenheid," in Waar die paaie saamwoon, opgedra aan P W Buys, Potchefstroom: Teologiese Publikasies, 131-145; en "John Calvin and the Belgic Confession," In die Skriflig 1983/4, 501-517.

9 In sy epogmakende bydrae getitel "Vragen rondom de belijdenis" behandel Berkouwer byvoorbeeld temas soos die waarheid, die geldigheid en die betekenis van die belydenis, en in verband daarmee dan hulle Skriftuurlike karakter, hulle menslike aard, die sogenaamde onderskeid tussen inhoud en vorm, en die vraag wat trou aan die belydenis werklik beteken G.C. Berkouwer, 1963. Vragen rondom de belijdenis, GTT 63, 1-41.

10 Venter, A. J. Kerk en belydenis, Potchefstroom: Die Evangelis, s.j. Venter sluit ook direk aan by die artikel en die formuleringe van Berkouwer.

11 W.D. Jonker, Bevrydende Waarheid. Die Karakter van die Gereformeerde Belydenis, Wellington, 


\section{TEOLOGIESE INHOUD, WIRKUNGSGESCHICHTE EN BLYWENDE RELEVANSIE}

In die derde plek beteken dit dat belydenisskrifte roep om Wirkungsgeschichte, lewende tradisie, 'n dinamiese geskiedenis van resepsie, uitleg, toeëiening en uitlewing. Trou aan die tradisie bestaan nie daarin dat formulerings bloot herhaal word nie. Erken van gesag bestaan nie in blinde weiering om verder te worstel oor hedendaagse uitdagings nie. Lojaliteit vra juis voortgaande Skrifondersoek, teologiese arbeid, soeke saam met die heiliges om die waarheid steeds beter te ken.

Wat die Nederlandse Geloofsbelydenis betref word dié noodsaak aan voortdurende kritiese omgang met die destydse voorveronderstellings, heersende lewensbeskouinge, stand van eksegetiese en teologiese kennis en beskikbare konseptuele raamwerke byvoorbeeld goed geïllustreer aan die hand van artikel 36 se opvattinge oor staat en kerk. Die relevansie vandag kan nie bloot daarin bestaan dat ons blindelings herhaal en aanvaar alles wat daarin staan nie. Egte trou vra ook om kritiese omgang met die tradisie self en met herkenning van toevallighede wat nie wesenlik tot die tradisie self behoort nie. ${ }^{12}$

Hugenote-Uitgewers, 1994. Hy bespreek die drie sogenaamde Formuliere van Eenheid, te wete die Nederlandse Geloofsbelydenis, die Heidelbergse Kategismus en die Dordtse Leerreëls, en in 'n laaste hoofstuk oor Gereformeerde belydenis vandag situeer hy Barmen en Belhar binne wat hy beskryf as ' $\mathrm{n}$ hedendaagse belydenisbeweging. As hy die Nederlandse Geloofsbelydenis se swaartepunte bespreek, behandel hy agtereenvolgens die leer van die Heilige Skrif, die oud-kerklike dogma wat gehandhaaf word, die radikale verdorwenheid wat geleer word, die weg van verlossing wat beskryf word, die kerklike en geloofspraktyke wat daaruit afgelei word, die ekklesiologie en sakramentologie wat daaruit volg (en hy bestee veel aandag aan die siening van die kerk), asook die sieninge van kerk en staat en die laaste oordeel wat gehuldig word, 55-91.

12 Oor Artikel 36 se aktuele belang is byvoorbeeld so onlangs as 2010 'n doktorale proefskrif by Potchefstroom geskryf, sien D.F. Muller, Die roeping van Suid-Afrikaanse owerhede binne ' $n$ grondwetlike demokrasie in die lig van artikel 36 van die Nederlandse Geloofsbelydenis, Potchefstroom, November 2010, volledig beskikbaaar op die internet, by http://dspace.nwu.ac.za/handle/10394/4395. Oor dieselfde tema, byvoorbeeld ook D.C.S. van der Merwe, 'Die verandering van artikel 36 van die NGB in Nederland in 1905: progressie of regressie?,' In die Skriflig 3 (11), 1969, 1-64; J.M. Vorster, 'Godsdiensvryheid in 'n toekomstige Suid-Afrika in die lig van artikel 36 van die Nederlandse Geloofsbelydenis', In die Skriflig 27 (3), 1993, 307-321; C.F.C. Coetzee, 'Godsdiensvryheid in die lig van artikel 36 NGB', NGTT 47 (1\&2), 2006, 143-157; P. Fourie, 'Godsdiensvryheid in die ban van NGB Art 36 - seën of vloek?', NGTT 47 (1\&2), 2006, 158-172. Geleerdes het al meermale aangetoon hoe filosofiese en politieke gedagtes geskoei op Artikel 36 bygedra het tot die fundering van apartheid, deur religieuse begronding te bied vir die selfverstaan van 'n sogenaamde Christelik-nasionale regering en die eksklusiewe en onderdrukkende ideologie en beleid wat daaruit gevloei het. Só was daar later ook, in die vroeë 1980s, 'n dramatiese oomblik toe 193 predikante van die drie wit Afrikaans-sprekende Gereformeerde kerke ' $n$ publieke getuienis gepubliseer het waarin hulle die destydse nuwe konsep grondwet verwerp het, met die argument, gebaseer op Artikel 36, dat hulle as Christene nie politieke mag kan deel met bevolkingsgroepe (volkere of rasse) wat potensieel mense kon insluit wat nie gelowiges is nie. Die destydse insluiting, al was dit in twee afsonderlike, eie huise van die parlement, van mense wat onderskeidelik as Kleurling en Indiër geklassifiseer was in terme van die apartheidswetgewing, was gevolglik vir hulle in stryd met hulle geloof en belydenis: 'Ons bely saam met die Nederlandse Geloofsbelydenis Artikel 36 dat die staat ' $n$ verantwoordelikheid het om sorg te dra dat die grondslae van die Christelike samelewing nie ondermyn word nie. Dit mak magsdeling met groepe wat die Bybelse grondwaarhede verwerp, prinsipieel onmoontlik.' In die kritiek op dié soort argument is egter eweneens van Artikel 36 gebruik gemaak. Vir kritiese reaksies teen dié soort gebruik van Artikel 36, sien byvoorbeeld W.D. Jonker, "Die koningskap van Christus en die staat in "n godsdienstig-pluralistiese land," Scriptura 12, 1984, 1-16; asook W.P. Esterhuyse, "Respons op "Die koningskap van Christus en die staat in 'n godsdienstig-pluralistiese land'," Scriptura 12, 1984, 16-19. Die konflik oor apartheid was dus reeds ook in dié baie spesifieke sin 'n konflik tussen twee uitleg-geskiedenisse van die Nederlandse 
Die saak van die blywende relevansie van ' $n$ tradisie is egter ingewikkelder. Volgens ' $n$ bekende opvatting is daar ten diepste net enkele dwaalleringe wat deur die eeue telkens weer in verskillende gedaantes herhaal - byvoorbeeld gnostiese motiewe. In die mate dat dit waar sou wees, is ' $n$ eerste vraag rondom die blywende relevansie van belydenisskrifte dus een van onderskeidingsvermoë, primêr een van herkenning. Herken ons nog in ons tyd en in nuwe gedaantes dieselfde versoekinge waarteen die belydenisse destyds verwoord is? Herken ons nuwe woordvoerders en gemeenskappe waarin dieselfde verleidinge teenswoordig beliggaam word - en is ons steeds bereid om hulle teen te staan, dalk op nuwe maniere, miskien helderder uitgespel as destyds (soos wat die Dordtse Leerreëls nodig geag is om standpunte reeds in die Nederlandse Geloofsbelydenis ingeneem nóg duideliker te bely?). In Suid-Afrika was daar telkens oomblikke waarin posisies en praktyke op dié manier in die naam van die Nederlandse Geloofsbelydenis krities gekonfronteer is. ${ }^{13}$

In beginsel is dit boonop moontlik dat daar wél nuwe uitdagings kan ontstaan, nuwe dwaalleringe, wat die evangelie verkondig op wyses wat deur ander as in stryd met die Woord geag word. Die tradisie ken so ' $\mathrm{n}$ oomblik as status confessionis, waarin nie die inhoud van bestaande belydenisse op die spel is nie, maar die evangelie self - en die geloofwaardige verkondiging of uitlewing daarvan. As Gereformeerdes in sulke oomblikke oordeel dat hulle op die mond geslaan is en nuut moet bely, is dit geen mosie van wantroue in bestaande belydenisskrifte, asof dié nie meer geldend en relevant sou wees nie, maar bloot die erkenning dat in ' $n$ lewende tradisie alles nooit finaal uitgespreek kan word nie. ${ }^{14}$

Die saak is egter nóg ingewikkelder, omdat daar nóg moontlikhede bestaan. Dis immers ook denkbaar dat gelowiges tot die oortuiging kan kom dat hulle juis wat die grondmotiewe van die belydenis betref dit nie langer meer eens is met hul eie tradisie nie. Dis moontlik dat hulle op grond van nuwe insigte en oortuigings verplig voel om innerlik afskeid te neem van die diepste grondslae van die tradisie self.

Daarmee word ' $n$ laaste moontlikheid egter duidelik - en die saak selfs nóg meer dramaties. Dis immers ook moontlik dat ons met ons hedendaagse insigte en oortuigings kan dwaal - en ten ónregte kan oordeel dat die tradisie verkeerd is. Dis immers voorstelbaar dat ons onsself - ten

Geloofsbelydenis. Die merkwaardige aan die verhaal was immers dat swart Gereformeerde gelowiges nie hulle rug op die tradisie en die belydenisse gekeer het omdat dié benut was om hulle uit te sluit en te onderdruk nie, maar omgekeerd hulle juis óp die tradisie beroep het teen (hierdie uitleg van) die tradisie. Hulle het die Gereformeerde tradisie, insluitende die Nederlandse Geloofsbelydenis, toegeëien as hulle eie.

13 Verskeie bekende Suid-Afrikaanse Gereformeerde teoloë het meermale oor belydenisskrifte en die Gereformeerde belydenistradisie nagedink en geskryf, ook in werke wat dikwels op kritiese tye " $n$ verskil sou maak, sien byvoorbeeld J.J.F. Durand, “'n Belydenis - was dit werklik nodig?," en "Belhar - Krisispunt vir die NG Kerke," albei in G.D. Cloete \& D.J. Smit (reds.), 'n Oomblik van waarheid, Kaapstad, Tafelberg, 1984, 39-48, 123-134; A.A. Boesak, Black and Reformed. Apartheid, liberation and the Calvinist tradition, Maryknoll, Orbis, 1984; G.D. Cloete, "Galatians 2:15-21 and the Belhar Confession (1986) in dialogue," in Living Theology, eds. L.D. Hansen, N.N. Koopman \& R. Vosloo, Wellington, Bible Media, 2011, 277-291; H.R. Botman, "Gereformeerdheid en die Belydenis van Belhar?'," Vraagtekens oor Gereformeerdheid?, red. W.A. Boesak \& P.J.A Fourie, Belhar, LUS, 1998, 94-11; R.S. Tshaka, "Confessional theology as belligerently public theology - How confessional theology relates to notions of Africanness and Reformedness," in Living Theology, eds. L.D. Hansen, N.N.

Koopman \& R. Vosloo, Wellington, Bible Media, 2011, 292-304.

14 Sien hieroor byvoorbeeld D.J. Smit, “A status confessionis in South Africa?”, JTSA 1984/47, 21-46, asook die gesaghebbende studies van U. Möller, "Status confessionis? Confessing our faith in the context of economic injustice," Reformed World, 1996, 46/3, 138-144; asook in sy vroeëre omvangryke studie Im Prozeß des Bekennens. Neukirchen-Vluyn: Neukirchener Verlag, 1999, wat almal goed bekend is in SuidAfrikaanse kringe. 
onregte - skaar aan die kant van dié teen wie die belydenis destyds uitgespreek is. Om dié rede pas ' $n$ self-kritiese gesindheid ons - presies op dié punte waar ons meen om van die belydenis se teologiese inhoud te verskil en afstand te neem. In sulke situasies is die ingewikkelde vereiste dat ons teen ons eie sekerhede in sal bly huiwer om tóg eers te vra of daar nie dalk wysheid van oordeel in die tradisie verskuil lê wat ons tans nog nie insien, maar wat ons dalk moet waak om nie te maklik prys te gee nie.

Kortom, die vrae van trou aan belydenisskrifte en hul blywende relevansie is kompleks. Om saam te vat, wat leer Skrif en teologie ons vandag, wat weet óns, dalk béter? Wat is daar in die Nederlandse Geloofsbelydenis aan historiese toevallighede, aan destydse veronderstellings wat ons nie meer só deel nie? Watter gedaantes neem die dwaalleer wat daar afgewys word in ons dag aan, teen welke hedendaagse misleiding wil die Nederlandse Geloofsbelydenis se grondmotiewe ons dalk waarsku? Herken ons hulle, kan ons hulle ontmasker? Is dit dalk nodig dat ons oor sommige van hulle méér sal sê, duideliker sal praat? Of is daar vandag nuwe versoekinge, gestaltes waarin die evangelie ten onregte verkondig word, wat vra om nuut te bely? Is ons dalk op punte oortuig dat die Nederlandse Geloofsbelydenis eintlik dwaal en dat ánder religieuse sieninge en strominge gelyk het, sodat ons ter wille van eerlikheid dit liewer openlik moet erken? Of behoort ons self-krities te vra of die Nederlandse Geloofsbelydenis nie tóg dalk iets sien wat ons tans nog nie begryp nie, aangesien dit óns insigte mag wees wat te kort skiet?

Dis alles te illustreer aan die hand van die Nederlandse Geloofsbelydenis. Die Nederlandse Geloofsbelydenis volg volgens Jonker die sogenaamde teologiese struktuur, die volgorde van God (artikels 1-11), Vader (12-17), Seun (18-21) en Heilige Gees (22-37). Veralgemenend (en met risiko van oor-vereenvoudiging) verwoord die eerste twee dele oor God die Vader asook die derde deel oor God die Seun redelik tradisionele leringe (alhoewel op talle punte destyds ook omstrede, was dit meesal nie die werklik kerk-verdelende faktore nie), en is die vierde deel oor die Gees die deel met die mees omstrede teologiese en die destyds verdelende beslissings. Anders gestel, die retoriese strategie was breedweg om die owerstes te oortuig van hulle trou aan die algemene Christelike leer (grootliks dele een tot drie) en hulle te onderskei van die Anabaptiste (grotendeels deel vier). ${ }^{15}$

Met die struktuur van die Belydenis van agter beskou, roep dit reeds vele vrae op oor die implikasies van die teologiese inhoud van die Belydenis in Suid-Afrikaanse kerklike en spesifiek Gereformeerde kringe vandag. Hoe staan ons (byvoorbeeld) vandag wat betref die Nederlandse Geloofsbelydenis se sieninge van die werklike teenwoordigheid van Christus in die sakramente en van die kerk; van die heil in Christus; van ons totale verdorwenheid, Gods voorsienigheid en dubbele Godskennis; van die Triniteit? Elk van dié temas is vandag hoogs omstrede en die kritiese vraag is in welke mate die Nederlandse Geloofsbelydenis bydra om ons denke en geloof hier plaaslik te help oriënteer, of nie.

15 Hierdie retoriese bedoelinge en strategie word byvoorbeeld duidelik uitgespel in die aangrypende begeleidende brief, gerig aan Koning Philips II van Spanje; vir die oorspronklike tekste daarvan, sien Bakhuizen van den Brink, De Nederlandse Belijdenisschriften, 62-69. Dit begin by voorbaat al direk met woorde wat duidelik dié soort strekking dra: "Door middel van deze brief willen wij U op de hoogte stellen van het lijden van Uw volk. Graag hadden wij ons persoonlijk bij U verdedigd tegen de beschuldigingen die men tegen ons inbrengt. Onze vijanden hebben echter zoveel valse aanklachten bij U ingediend, dat wij de kans niet krijgen voor $U$ te verschijnen om onze zaak te bepleiten. Wij worden zelfs verbannen, vermoord en verbrand. Nergens zijn we veilig. Daarom vragen wij U of U naar onze klachten wilt luisteren." 


\section{TEN SLOTTE: TEOLOGIESE INHOUD AS BEVRYDENDE WAARHEID}

In dié lig is dit tog merkwaardig dat en hoe die teologiese inhoud van belydenisskrifte op ' $\mathrm{n}$ dag êrens vir gelowiges in dié tradisies opnuut soveel betekenis kan kry dat hulle dit inderdaad as "bevrydende waarheid" belewe. Dit het met die Nederlandse Geloofsbelydenis gebeur tydens die ontstaan van die Belydenis van Belhar (1982/1986). ${ }^{16}$ Op vele maniere kan die sleutel rol van die Nederlandse Geloofsbelydenis in dié geskiedenis aangetoon word. ${ }^{17}$

Dit word eerstens duidelik uit die wyse waarop die Nederlandse Geloofsbelydenis die daad van belydenis direk geïnspireer het - byvoorbeeld in die self-verstaan van die 1982-Sinode oor wat hulle aan die doen was, ${ }^{18}$ in die beslissende rol van 1 Petrus 3:15-16 sowel in die Nederlandse Geloofsbelydenis as in die Sinode se besluite, ${ }^{19}$ asook in die feit, die styl en die strekking van die

16 Vir die geskiedenis en die inhoud van die Belydenis van Belhar, sien byvoorbeeld ook, benewens Cloete \& Smit, J.G. Botha \& P.J. Naudé, Goeie nuus om te bely, Wellington, Bybel-Media, 2010 (English translation, Good news to confess, Wellington, Bible Media, 2010); Botha \& Naudé, Op weg met Belhar. Goeie nuus vir gister, vandag en môre, Pretoria, Van Schaik, 1998; and P.J. Naudé, Neither Calendar nor Clock. Perspectives on the Belhar Confession, Grand Rapids, Wm. B. Eerdmans, 2010.

17 Sien byvoorbeeld die Belgiese publikasie De Belijdenis van Belhar en haar betekenis voor ons, Informatie- en bezinningsmateriaal voor de kerken van de Verenigde Protestantse Kerk in België (ook in Frans), 2000. Uiteraard was dit nie die enigste invloed agter die Belydenis van Belhar nie. Verskeie ander trajekte en tradisies kan natuurlik ook onderskei en meer uitvoerig aangedui word. So is daar onder andere byvoorbeeld ook die invloed van die gebeure rondom die Teologiese Verklaring van Barmen; sien daarvoor onder andere N.J. Horn, 'From Barmen to Belhar and Kairos', On reading Karl Barth in South Africa, ed. C. Villa-Vicencio, Grand Rapids, Wm. B. Eerdmans, 1988, 105-120; asook D.J. Smit, 'Barmen and Belhar in conversation - A South African perspective', NGTT 47, 1\&2, 291-302. Vir die invloed van Karl Barth, sien byvoorbeeld P.J. Naudé, Neither Calendar nor Clock, 77-103. Vir die belangrike invloed van ontwikkelinge binne die geledere van die destydse beweging binne die Gereformeerde kerke bekend as die Belydende Kring, sien byvoorbeeld J.N.J. (Klippies) Kritzinger, 'Celebrating communal authorship: the Theological Declaration of the Belydende Kring (1979) and the Belhar Confession', Studia Historiae Ecclesiasticae Vol 36, Supplement, July 2010, internet http://uir.unisa.ac.za/handle/10500/4600. Ook verskeie ander invloede kan egter onderskei en aangetoon word.

18 In die periode direk ná die aanvaarding van die konsep belydenis van Belhar in 1982 is dié konsep in uitvoering van die besluit oraloor in die destydse NGSK bespreek, in gemeentes en ringe. Tydens dié geleenthede het prof. Gustav Bam, die dosent in Praktiese Teologie aan die Universiteit van WesKaapland wat as amptelike adviseur die oorspronklike suggestie in die Sinode gelaat het dat méér dalk nodig was as slegs die verklaring van 'n status confessionis, dikwels in gemeentes gepreek aan die hand van 1 Pet 3:15-17. Een weergawe van dié preke, met die tema "Gereed om "n antwoord te gee" is gepubliseer in die amptelike versameling van preke oor Belhar wat deur die Sinode gepubliseer en versprei is, bekend as Eenheid, Versoening, Geregtigheid. Preke rondom die Belydenis van Belhar, Belhar, LUS, Sinodale Kommissie vir Publikasie en Kommunikasie van die NGSK, 1988, 15-19.

19 Op die buiteblaaie van die oorspronklike weergawes van die Nederlandse Geloofsbelydenis was dit naamlik die Bybelgedeelte wat aangehaal en afgedruk was, elke keer weer en in die verskillende tale. Aan die einde van die lang voorwoord, in die vorm van ' $n$ begeleidende brief aan Koning Philip, waarin verduidelik en gemotiveer word wat hulle aan die doen was en waarom, is dit een van die vyf Bybelgedeeltes wat aangehaal word, waarin "gelowiges deur die Nuwe Testament vermaan word om belydenis van hulle geloof voor die mense te gee." Dit was duidelik dié teks in die lig waarvan die oorspronklike skrywers hulle eie optrede en bedoelinge verstaan het. Presies dieselfde het gegeld tydens die Sinodes van die NGSK waartydens hierdie besluite geneem is. Só het die heel eerste kommissie al hulle verslag geopen met die woorde: "U kommissie het in die uitvoering van sy taak 1 Pet 3:15-16 as rigsnoer geneem: 'In julle harte moet daar net 'n heilige eerbied wees vir Christus die Here. Wees altyd bereid om ' $n$ antwoord te gee aan elkeen wat van julle ' $n$ verduideliking eis oor die hoop wat in julle is. Maar doen dit met beskeidenheid en met eerbied vir God. Sorg dat julle gewete skoon bly',", Handelinge van die Drie-en-Twintigste Vergadering van die Hoogeerwaarde Sinode van die Nederduitse 


\section{Begeleidende Brief..$^{20}$}

Dit word tweedens duidelik uit die wyse waarop die Nederlandse Geloofsbelydenis die inhoud van die Belhar stempel - by uitstek wat betref die Nederlandse Geloofsbelydenis se ekklesiologie. In die dekade lange debatte wat Belhar vooraf gegaan het sou teoloë soos Jonker ${ }^{21}$ en J.J.F. (Jaap) Durand ${ }^{22}$ hulle telkens uitdruklik op artikels 27-29 van die Nederlandse Geloofsbelydenis beroep in stryd met heersende opvattinge oor die volkskerk en die pluriformiteit van kerke. ${ }^{23}$

Gereformeerde Sendingkerk in Suid-Afrika op 22 September tot 6 Oktober 1982 in Belhar, G.10.3, Bylae Nr. 10.3, punt 1, 753. Verder aan in dieselfde verslag word dan besluit "dat die Begeleidende Brief deurgaans saam met die Belydenis sal deurgegee word in die besonder aan die kerkrade en ringe; dat die Sinode uitdruklik verklaar, nie alleen dat hy die belydenis aanvaar nie, maar dat hy dit suiwer en alleen doen in die gees en met die verwagting van 1 Pet 3:15-17 en van die begeleidende brief," Handelinge van die Drie-en-Twintigste Vergadering van die Hoogeerwaarde Sinode van die Nederduitse Gereformeerde Sendingkerk in Suid-Afrika op 22 September tot 6 Oktober 1982 in Belhar, G.10.3, Bylae Nr. 10.3, punte $6 \& 7,753$.

20 Vir die volle teks van die Begeleidende Brief, sien die amptelike webwerf van die VGKSA, by http:// www.vgksa.org.za/documents/Belydenis\%20van\%20Belhar.pdf Vir 'n meer uitvoerige bespreking van die inhoud en strekking van die Brief, sien byvoorbeeld D.J. Smit, "No other motives would give us the right"' - Reflections on contextuality from a Reformed perspective', Studies in Reformed Theology 8. Christian Identity in Cross-Cultural Perspective, eds. M.E. Brinkman \& D. van Keulen, Zoetermeer: Meinema, 2003, 130-159. Weer eens kan daar geen twyfel oor bestaan dat hulle met dié gees bedoel het om te handel in die gees van die oorspronklike begeleidende brief by die Nederlandse Geloofsbelydenis nie.

21 Vir Jonker, sien byvoorbeeld veral W.D. Jonker, Aandag vir die kerk, Potchefstroom, Die Evangelis, 1965; Om die regering van Christus in sy kerk, Pretoria, Unisa, 1965; Die Sendingbepalinge van die Ned. Geref. Kerk van Transvaal, Potchefstroom, Studie-groep kerk en Wêreld, 1962. Hy argumenteer in groot detail met behulp van die Nederlandse Geloofsbelydenis se artikels oor die kerk vir sigbare kerkeenheid en teen die destydse kerkordelike reëlings en praktyke. Sien byvoorbeeld net sy bespreking by Aandag vir die kerk, 26-30.

22 Vir Durand, sien byvoorbeeld veral J.J.F. Durand, Una sancta catholica in sendingperspektief, Amsterdam, Ten Have, 1961; 'Calvyn as ekumeniese gees', NGTT 1964, 167-182; 'Ware ekumenisiteit - die Gereformeerde Vaders', Die Ekumene, reds. W.A. Landman et al, Stellenbosch, Kosmo-Uitgewery, 1964, 24-39 (met bladseye 38-39 uitdruklik gewy aan die Nederlandse Geloofsbelydenis, artikels 27-29); 'Kerkverband - wese of welwese?', Die eenheid van die kerk, reds. P. Meiring \& H.I. Lederle, Kaapstad: Tafelberg, 1979, 73-77.

23 Alreeds in die inleiding van Belhar is daar duidelike sinspelings op Artikel 27 van die Nederlandse Geloofsbelydenis, met sommige van die uitdrukkings, maar ook selfs die logika en die volgorde van sekere van die uitsprake wat dieselfde is, alhoewel hierdie oortuigings uiteraard 'n nuwe relevansie vind in die totaal verskillende historiese konteks van die die apartheid ekklesiologie, teologie en samelewing. "Ons glo en bely ' $n$ enige katolieke of algemene kerk, "n heilige vergadering van almal wat waarlik in Christus glo, wat almal hulle volle saligheid in Jesus Christus verwag en in sy bloed gewas is, geheilig en verseël deur die Heilige Gees. Hierdie kerk was daar van die begin van die wêreld af en sal tot die einde daar wees, want Christus is ' $n$ ewige Koning, wat nooit sonder onderdane kan wees nie. En hierdie heilige kerk word deur God teen die woede van die hele wêreld bewaar, alhoewel dit soms ' $n$ tyd lank baie klein is en dit in die oë van die mense lyk asof dit tot niet gegaan het - soos die Here vir Hom gedurende die gevaarlike tyd onder Agab sewe duisend mense bewaar het wat nie voor Baäl gekniel het nie. Verder is hierdie heilige kerk nie geleë in, gebonde aan of bepaal tot 'n sekere plek of sekere persone nie, maar is die oor die hele wêreld versprei en verstrooi. Tog is dit met hart en wil en deur die krag van die geloof in een en dieselfde Gees saamgevoeg en verenig." Interessant genoeg, in 'n bydrae wat geskryf is ter huldiging van Jaap Durand verwys J.N.J. (Klippies) Kritzinger juis na die oortuiging in die inleiding van Belhar dat die Drieënige God die kerk sal bewaar en versorg "tot aan die einde toe" en skryf dit daaraan toe dat Durand, wat " $n$ lid was van die kommissie wat die konsep belydenis geformuleer het, "'n persoon van goeie hoop" is. Die woorde én die oortuiging wat hier bely word spruit uiteraard reeds uit die woorde van Artikel 27 van die Nederlandse Geloofsbelydenis ("en sal tot die einde daar wees"), wat 
Die neerslag van dié bydraes - en uiteraard van vele ander - is duidelik te sien in die inleiding van Belhar en die eerste artikel oor die eenheid van die kerk $^{24}$. Op die heel eerste en voorlopige handgeskrewe ontwerp van Belhar staan verwysings na die betrokke gedeeltes in die Nederlandse Geloofsbelydenis (en die Heidelbergse Kategismus) uitdruklik bo-aan. ${ }^{25}$

Dit word derdens duidelik uit die wyse waarop die Nederlandse Geloofsbelydenis die gees van Belhar motiveer, die vaste voorneme om dié oortuigings te bely en uit te leef ondanks verset

op hulle beurt weer berus op bybelse beloftes; sien J.N.J. Kritzinger, 'Jaap Durand - man of good hope', Discerning God's justice in church, society and academy, eds. E. Conradie \& C. Lombard, Stellenbosch, Sun Press, 2009, 209-210.

24 In Artikel 29, by voorbeeld, word 'n onderskeid gemaak tussen ware en valse vorme van die kerk en hierdie onderskeiding maak dit moontlik en soms ook - met verwysing na 'n status confessionis - nodig om hierdie soort onderskeiding aan te bring, oftewel, in die woorde van die Nederlandse Geloofsbelydenis, om te vra of die evangelie suiwer gepreek en gehoor en die sakramenete korrek bedien en gevier word, of wanneer sommige in die kerk nie dalk vir hulleself meer gesag probeer toeëien as vir die Woord van God nie: "Ons glo dat ons sorgvuldig en met groot oplettendheid uit die Woord van God behoort te onderskei watter kerk die ware kerk is, aangesien al die sektes wat daar vandag in die wêreld is, hulle ten onregte die naam kerk toeëien. Ons praat hier nie van die huigelaars wat in die kerk met die goeies vermeng is en tog nie aan die kerk behoort nie alhoewel hulle uiterlik daarin is; maar ons sê dat 'n mens die liggaam en die gemeenskap van die ware kerk moet onderskei van al die sektes wat beweer dat hulle die kerk is. Die kenmerke waaraan ons die ware kerk kan uitken, is die volgende: Wanneer die kerk die evangelie suiwer preek, die sakramente suiwer bedien soos Christus dit ingestel het en die kerklike tug gebruik om die sondes te straf - kortom, wanneer almal hulle ooreenkomstig die suiwere Woord van God gedra, alles wat daarmee in stryd is, verwerp en Jesus Christus as die enigste Hoof erken. Hieraan kan ons met sekerheid die ware kerk uitken, en niemand het die reg om hulle daarvan af te skei nie. Vervolgens, aangaande die lidmate van die kerk: Ons kan hulle uitken aan die kenmerke van die Christene, naamlik hulle geloof dat hulle die enigste Verlosser Jesus Christus aangeneem het en dat hulle daarna die sonde ontvlug, die geregtigheld najaag, die ware God en hulle naaste liefhet, nie na regs of links afwyk nie en hulle sondige natuur met sy werke kruisig. Hiermee sê ons nie dat daar nie nog groot swakheid in hulle is nie; inteendeel, deur die Gees stry hulle juis al die dae van hulle lewe daarteen, terwyl hulle altyd weer hulle toevlug neem tot die bloed, die dood, die lyding en gehoorsaamheid van die Here Jesus Christus, in wie hulle deur die geloof in Hom vergewing van hulle sondes het. Wat die valse kerk betref: dit skryf aan homself en sy besluit meer mag en gesag toe as aan die Woord van God; dit wil homself nie aan die juk van Christus onderwerp nie; dit bedien die sakramente nie soos Christus dit in sy Woord beveel het nie, maar neem weg en voeg by na eie goeddunke; dit vertrou meer op mense as op Christus, en dit vervolg hulle wat volgens die Woord van God heilig lewe en wat die valse kerk oor sy euwels, gierigheid en afgodery bestraf. Hierdie twee kerke kan maklik uitgeken en van mekaar onderskei word."

25 Sommige van die oorspronklike handgeskrewe kopieë van die Belydenis van Belhar is beskikbaar in die argief van die Verenigende Gereformeerde Kerk in Suider-Afrika in die gebou van die Fakulteit Teologie in Stellenbosch. 
26 Dié motief is duidelik aanwesig, en nie alleen in die hele gebeure en die dáád van belydenisvorming, mét ' $\mathrm{n}$ begeleidende brief, bewus van die verdere teenstand wat dit mag oproep, bo en behalwe die onderdrukking en vervolging wat reeds intens ervaar is nie - immers ook in en tydens die Sinode self, met predikante wat lede van die Sinode was maar skielik sonder verhoor in hegtenis geneem is letterlik tydens die duur van die sitting. Die motief word naamlik ook uitdruklik verwoord in die slot van Belhar, as gesê word: "Ons glo dat die kerk geroep word om dit alles te bely en te doen, in gehoorsaamheid aan Jesus Christus, sy enigste Hoof, al sou ook die owerhede en verordeninge van mense daarteen wees en al sou straf en lyding daaraan verbonde wees. Jesus is die Heer." Die Begeleidende Brief by die Nederlandse Geloofsbelydenis verwoord dwarsdeur dieselfde gees en toon, byvoorbeeld as gesê word: "U mag, mijnheer de koning, als U ons na het aanhoren van onze klachten schuldig bevindt, de brandstapels en andere straffen in Uw koninkrijk vermeerderen ... Wij danken echter onze God dat het bloed van onze broeders, voor onze zaak, of liever voor de zaak van Jezus Christus vergoten, tot God roept. De verbanningen, gevangenisstraffen, pijnbanken, verbeurdverklaringen, martelingen en andere verdrukkingen bewijzen wel dat het ons niet om onszelf te doen is. Wij zouden het immers veel gemakkelijker kunnen hebben, als wij deze leer niet verdedigden. Wij vrezen echter God, verschrikt door het dreigende woord van Jezus Christus, die zegt dat Hij ons verloochenen zal voor God Zijn Vader, als wij Hem voor de mensen verloochenen. Omdat wij weten dat wie Christus wil volgen, zijn kruis op moet nemen en zichzelf moet verloochenen, ondergaan wij al deze martelingen geduldig ... Men vervolgt ons niet alleen als vijanden van $U$ en van de samenleving, maar ook als vijanden van God en van Zijn kerk. Daarom vragen wij $U$ of $U$ ons wilt beoordelen naar onze geloofsbelijdenis die wij $U$ hierbij anbieden. Wij zijn bereid deze belijdenis zonodig met ons eigen bloed te bekrachtigen. Hopelijk zult U erkennen dat men ons ten onrechte scheurmakers, opstandelingen en ketters noemt. Want wij belijden niet alleen de hoofdpunten van het christelijke geloof, vervat in de apostolische geloofsbelijdenis, maar de gehele leer die Jezus Christus ons geopenbaard heeft tot leven, gerechtigheid en behoud ... Wij beven bij deze woorden en schrikken van de dreigementen van hen die macht hebben ons lichaam te verbranden. Maar anderzijds horen wij de apostel zeggen: Ook al zouden wij, of een engel uit de hemel, u een Evangelie verkondigen, afwijkend van wat wij u verkondigd hebben, die zij vervloekt!"

27 Trouens, dis moontlik om te argumenteer, soos wat vele wel doen, insluitende Jaroslav Pelikan in sy gesaghebbende Credo, New Haven: Yale University Press, 2002, byvoorbeeld 59 e.v., dat die belydenis dat Jesus die Heer is die oer-belydenis agter álle Christelike geloofsbelydenisse is, die eintlike "inhoud" van die belydenis. Dié soort aanspraak word telkens gemaak met beroep op die ryk-geskakeerde maniere waarop die oer-belydenis dat Jesus Christus die Heer is in die vroeë kerk en in die Nuwe Testamentiese geskrifte gefunksioneer het. Aanvanklik was dit ' $n$ roemende reaksie op die opstanding van Jesus Christus, 'n belydenis van hulle diepste geloof dat Hy self hulle Heer en God is. Daarmee het dit egter dadelik ' $n$ hermeneutiese funksie begin vervul, en het hulle die Ou Testamentiese boeke, hulle geloofsdokumente, begin lees met dié bril, met die oortuiging dat Hy die Here van die skepping en die geskiedenis was en is, en met die verwagting dat hierdie boeke van Hóm getuig. In die Briewe wat geskryf is om die evangelie te verkondig en in die Evangelies wat sou volg om te vertel wie Jesus waarlik is word hierdie oortuiging die inhoud van die vroeg-Christelike verkondiging, prediking en onderrig, soos die preke in Handelinge ook aangrypend laat blyk. God het Hóm Here en Christus gemaak - dís die evangelie en dís hulle prediking. Daarmee word dié evangelie die grondslag van hulle onderlinge eenheid met mekaar, ondanks alle verskille en spanninge, sodat hulle vermaan word om almal te aanvaar wat bely dat Christus die Here is, aangesien niemand dit kan doen buiten die één Heilige Gees wat hulle saambind, ondanks alle verdelinge en agterdog nie. Wie trouens ontken dat Hy die Here is, dat Hy waarlik in die vlees gekom het en aan die kruis gesterf het, is besig met dwaalleer en hang ' $n$ valse evangelie aan, soos die Briewe van Johannes begin aantoon. En teenoor die aansprake van die samelewing, kultuur en magspolitiek en ekonomie dat die keiser heer is bely die vroeë kerk - vrymoedig en moedig, in die openbaar, al kos dit hulle verguising en vervolging - dat Christus die Here is, en daarmee word die belydenis wat aanvanklik net hulle geloof roemend verwoord het tot ' $n$ verreikende politieke aanspraak, wat deur die eeue sou bly weergalm, telkens weer - tot letterlik in die woorde van Barmen en Belhar. 28 Die verwysing na 1 Pet 3:15 is die heel laaste Bybelse verwysing in die Belydenis van Belhar. "Ons 
Botman het onlangs gewys op die belang van dié oortuiging as sleutel tot Belhar. ${ }^{29}$ Dié verbande word byvoorbeeld dramaties verwoord in die slotwoorde van Allan Boesak se 1981-toespraak voor ABRECSA met die titel "Black and Reformed" (uit die gelyknamige bundel, 1984), as hy doelbewus die destydse optrede dui in die lig van die gees en selfs die letterlike woorde van die Nederlandse Geloofsbelydenis.

So the confession that Jesus Christ is Lord of my life is not spiritual escapism. It is a confession with profound implications for the whole of life. It is a fundamental theological affirmation of the place of the Christian in this world, and it firmly sets the limits of the powers of this world. It places us within the best tradition of the Christian church through the ages ... It is comfort, but it is more: it is ... quiet, subversive piety ... (I)n this struggle I am inspired by the words of the Belgic Confession: 'The faithful and elect shall be crowned with glory and honor ... and their cause, which is now condemned by many judges and magistrates as heretical and impious, will then be known to the cause of the Son of God.' This, also, is our tradition and is worth fighting for." ${ }^{30}$

glo dat die kerk geroep word om dit alles te bely en te doen, in gehoorsaamheid aan Jesus Christus sy enigste Hoof, al sou ook die owerhede en verordeninge van mense daarteen wees en al sou straf en lyding daaraan verbonde wees. Jesus is die Heer. Aan dié enige God, Vader, Seun en Heilige Gees, kom toe eer en heerlikheid in ewigheid," met as Bybelse verwysings in die kantlyn, Efes 4:15-16, Hand 5:29-33, 1 Pet 2:18-25 en 1 Pet 3:15-18. Daar was ook al vroeër in die Belydenis verwysings na Artikel 28 van die Nederlandse Geloofsbelydenis, byvoorbeeld in die geïmpliseerde oortuiging dat afkoms of enige ander toestand geen gelowige uitsluit van lidmaatskap van die kerk nie, asook in die uitdrukking dat die eenheid ook daarin sigbaar word dat gelowiges mekaar dien en onderling opbou volgens hulle onderskeie gawes. In die geheel kan lesers waarskynlik verskillende motiewe uit Artikel 28 van die Nederlandse Geloofsbelydenis herken in Belhar: "Ons glo - aangesien hierdie heilige vergadering 'n versameling is van hulle wat verlos word en daarbuite geen saligheid is nie - dat niemand, wat sy stand en status ook al is, hom in selftevredenheid van hierdie vergadering afsydig mag hou nie; inteendeel, almal is verplig om daarby aan te sluit en hulle daarmee te verenig om die eenheid van die kerk te bewaar deur hulle almal - as lede van een en dieselfde liggaam - aan sy leer en tug te onderwerp, die nek onder die juk van Jesus Christus te buig en volgens die gawes wat God aan elkeen gegee het, die broers in die opbou van hulle geloof te dien. En om dit beter te kan doen, is dit volgens die Woord van God die plig van alle gelowiges om hulle af te skei van hulle wat nie aan die kerk behoort nie, en hulle by dié vergadering aan te sluit, waar God dit ook al gevestig het, selfs al sou regerings en wette van regeerders daarteen wees en daarvoor die dood- of lyfstraf oplê. Daarom handel almal wat hulle van hierdie ware kerk afskei of nie daarby aansluit nie, in stryd met die bevel van God" (kursief bygevoeg). In die kerklike debatte in Gereformeerde kringe in Suid-Afrika is dikwels beroep gedoen op hierdie artikels uit die NGB deur diégene wat krities was oor die skeiding wat in kerke tussen gelowiges gemaak is op grond van ras.

29 H.R. (Russel) Botman het dié oortuiging verwoord tydens 'n paneelbespreking op 12 Mei 2011 tydens die Sinodesitting van die NG Kerk van die Wes- en Suid-Kaap, volgens ' $n$ berig in die dagblad Die Burger, geskryf deur die joernalis Neels Jackson. Dié berig is op die internet toeganklik by http://www. dieburger.com/Suid-Afrika/Nuus/Eenheid-moet-nou-volg-20110512.

30 A.A. Boesak, Black and Reformed. Apartheid, Liberation, and the Calvinist Tradition, Maryknoll, Orbis, 1984, 83-99. Dit is sonder meer by enige aandagtige deurlees duidelik waarom die beskrywing van die laaste oordeel in Artikel 37 soveel troos bied aan dié gelowiges wat ly en onregverdig beskulding en behandel word in die geskiedenis en waarom Boesak gevolglik daartoe aangetrokke gevoel het om dié oortuigings toe te eien vir homself en vir sy mede-gelowiges. "Ons glo ten slotte, in ooreenstemming met die Woord van God, dat, wanneer die tyd gekom het wat die Here bepaal het - dié tyd is vir alle skepsels onbekend - en die getal uitverkorenes volledig sal wees, ons Here Jesus Christus met groot heerlikheid en majesteit uit die hemel sal kom, liggaamlik en sigbaar, soos Hy opgevaar het (Hand. 1:11), om Homself as Regter oor die lewendes en dooies aan te kondig, terwyl Hy hierdie ou wêreld aan vuur en vlam sal prysgee om dit te suiwer ... (D)an sal die geheime bedrog en huigelary van die mense in die openbaar voor almal oopgevlek word. Daarom is die gedagte aan hierdie oordeel vir die oortreders en goddeloses met reg ontsettend en skrikwekkend maar vir die vromes en uitverkorenes begeerlik en troosryk. Want dan sal hulle volle verlossing voltooi word, en hulle sal daar die vrugte ontvang van moeite en lyding 
Ongeag van die vraag hoe - dalk waarderend, dalk krities, dalk sinies en skepties - mense ook mag oordeel oor dié hernieude toeëiening van die teologiese inhoud van ' $n$ 16e eeuse belydenisdokument uit veraf en vreemde lande en tye, bly dié Suid-Afrikaanse storie 'n merkwaardige demonstrasie van die werking van ' $n$ belydenis-tradisie. Die geloofsinhoud kan op ' $n$ dag nuwe aktualiteit en betekenis krt, vir mense in totaal nuwe omstandighede en gekonfronteer met radikaal ander en nuwe vrae. Die merkwaardige van die Suid-Afrikaanse ervaring was boonop dat gelowiges hulle op een en dieselfde tradisie beroep het maar met radikaal teenoorstaande oortuigings. Presies dit was egter immers óók al die geval tydens die ontstaan van die Nederlandse Geloofsbelydenis. Die eerste figure het hulle op die Christelike evangelie beroep, soos wat hulle dit in daardie historiese oomblik verstaan het, net om te vind dat ander nie dié evangelie op dieselfde wyse verstaan en dieselfde gevolgtrekkings daaruit maak nie, met bloedige en tragiese gevolge. Dis juis hierdie ambiguïteit van die geloof en die belydenis wat ons herdenk in dié dae as ons hier in Suid-Afrikaanse kringe terugdink aan gebeure, figure en dokumente van 450 jaar gelede, ver van hier.

\section{KEY WORDS}

Confessio Beligica

Reformed confessions

Guido de Bres

Belhar Confession

Willie Jonker

Allan Boesak

\section{TREFWOORDE}

Nederlandse Geloofsbelydenis

Gereformeerde belydenisskrifte

Guido de Bres

Belydenis van Belhar

Willie Jonker

Allan Boesak

\section{KONTAKBESONDERHEDE}

Prof DJ Smit

Fakulteit Teologie

Privaatsak X1

7602 MATIELAND

Kant: 0218083258

Huis:021 8801921

E-pos: djs1@sun.ac.za

\footnotetext{
wat hulle gedra het. Hulle onskuld sal deur almal erken word, en hulle sal die verskriklike wraak sien wat God sal voltrek oor die goddeloses wat hulle in hierdie wêreld wreed vervolg, verdruk en gekwel het. Maar die goddeloses sal deur die getuienis van hulle eie gewete tot erkenning van hulle skuld gebring word; hulle sal onsterflik word dog slegs om gepynig te word in die ewige vuur wat vir die duiwel en sy engele voorberei is (Matt. 25:41). Die gelowiges en uitverkorenes, daarenteen, sal met heerlikheid en eer gekroon word. Die Seun van God sal hulle naam voor God, sy Vader (Matt. 10:32), en sy uitverkore engele bely; alle trane sal van hulle oë afgevee word (Op. 21:4). Dan sal dit bekend word dat hulle saak, wat tans deur baie regters en owerhede as ketters en goddeloos veroordeel word, die saak van die Seun van God is. En as ' $n$ beloning uit genade sal die Here self hulle so " $n$ heerlikheid gee as wat die hart van ' $\mathrm{n}$ mens nooit kon bedink nie. Daarom verwag ons hierdie groot dag met sterk verlange om die beloftes van God in Jesus Christus, ons Here, ten volle te geniet." Ook na hierdie woorde hoor 'n mens verwysings en sinspelinge in die konklusie van Belhar.
} 